\title{
PATH ANALYSIS ON THE FACTORS ASSOCIATED WITH MOBILE VCT OF HIV SERVICE UPTAKE AMONG MEN WHO HAVE SEX WITH MEN IN SURAKARTA, CENTRAL JAVA
}

\author{
Nadia Ayu Irma Nindiyastuti'), Hanung Prasetya²), Bhisma Murti1) \\ ${ }^{1)}$ Masters Program in Public Health, Universitas Sebelas Maret \\ ${ }^{2)}$ School of Health Polytechnics, Ministry of Health Surakarta
}

\begin{abstract}
Background: Men who have sex with men (MSM) are the most vulnerable risk group for HIV infection. This study aimed to examine factors associated with mobile voluntary and counselling test (VCT) of HIV service uptake among MSM in Surakarta using the Theory of Planned Behavior (TPB) and path analysis model.

Subjects and Method: A cross sectional study was conducted in Surakarta, Central Java, from October to November 2018. A sample of 200 MSM was selected by fixed disease sampling, including $50 \mathrm{MSM}$ who used mobile VCT service and $150 \mathrm{MSM}$ who did not use mobile VCT service. The dependent variable was mobile VCT use. The independent variables were intention, attitude, cues to action, perceived benefit, perceived barrier, and perceived susceptibility. The data were collected by questionnaire and analyzed by path analysis

Results: Mobile VCT of HIV service uptake was positively and directly associated with strong intention $(b=1.81 ; 95 \% C I=0.91$ to $2.72 ; p<0.001)$, positive attitude $(b=1.84 ; 95 \%$ $\mathrm{CI}=0.78$ to $2.90 ; \mathrm{p}=0.001)$, self-efficacy $(\mathrm{b}=2.17 ; 95 \% \mathrm{CI}=1.22$ to $3.12 ; \mathrm{p}<0.001)$, and peer support $(b=1.31 ; 95 \% \mathrm{CI}=0.43$ to $2.18 ; \mathrm{p}=0.003)$. It was indirectly associated with peer support through intention, attitude, and self-efficacy.

Conclusion: Mobile VCT service uptake is positively and directly associated with strong intention, positive attitude, self-efficacy, and peer support. It is indirectly associated with peer support through intention, attitude, and self-efficacy.
\end{abstract}

Keywords: mobile VCT service uptake, Theory of Planned Behavior

\section{Correspondence:}

Nadia Ayu Irma Nindiyastuti. Masters Program in Public Health, Universitas Sebelas Maret, Jl. Ir. Sutami 36 A, Surakarta 57126, Central Java, Indonesia.

Email: nadiaayu21051992@gmail.com. Mobile: 081252097440.

The $5^{\text {th }}$ International Conference on Public Health Best Western Premier Hote], Solo, Indonesia, February 13-14, $2019 \mid 156$ https://doi.org/10.26911/theicph.2019.02.01 